\title{
An Introduction to Halliday's Systemic Functional Linguistics
}

\author{
Wael Abdulrahman Almurashi \\ A Lecture Assistant \\ Department of Languages and Translations \\ Faculty of Science and Arts \\ Taibah University \\ Kingdom of Saudi Arabia
}

Received: April 16, 2016 Accepted: May 3, 2016 Published: May 6, 2016

doi:10.5296/jsel.v4i1.9423 URL: http://dx.doi.org/10.5296/jsel.v4i1.9423

\begin{abstract}
Numerous theories have been successful in accounting for aspects of language. One of the most substantial theories is Halliday's Systemic Functional Linguistics (often SFL), which has been employed in the literature on linguistics and applied linguistics. This paper aims to introduce Halliday's SFL with a focus on an overview of SFL as a linguistic tradition largely developed by Michael Alexander Kirkwood Halliday (often M.A.K. Halliday). Furthermore, this introduction compares SFL to other linguistic traditions, such as the transformational generative linguistics represented by Noam Chomsky and Bloomfield's structural tradition. This research also explains the key elements of SFL, SFL as an applicable tradition, examples of the value of applying SFL in detail, and finally, presents the benefits associated with working with SFL as a communicative motivation in learning a language.
\end{abstract}

Keywords: Linguistic tradition, Field, Tenor, Mode, Transitivity, Theme, Rheme, Transitivity 


\section{Introduction}

In the early 20th century, linguistics has witnessed a considerable number of theories and each one has its distinct orientations, trends, and subjects of study. However, most of these theories, such as Halliday and Chomsky's traditions, have been initiated by a number of followers or independently. In addition, each theory has been successful in accounting for aspects of language from a certain perspective. One of the most substantial theories is Halliday's SFL that has attracted the most attention and has been frequently employed in the literature on linguistics and applied linguistics. This paper aims to introduce Halliday's SFL. It will discuss a number of aspects about it, namely, the background of the SFL as a linguistic tradition, SFL compared to other linguistic traditions, the key elements of the SFL, SFL as an applicable tradition, examples of the value of applying SFL, and finally, the benefits associated with working with SFL.

\section{The Background to SFL as a Linguistic Tradition}

SFL is an approach to language developed largely by M.A.K. Halliday and his followers during the 1960s in the United Kingdom, and later in Australia (O'Donnell 2012, p. 1). SFL is built on previous works of some influential linguists such as Bronislaw Malinowski and J.R. Firth. Bronislaw Malinowski was a polish anthropologist who did most of his works based in England (O'Donnell 2012, p. 5). The second linguist is J.R. Firth who established linguistics as a discipline in Britain. He developed Malinowski's theory about the centrality of the context of situation and applied it through his linguistic model. In addition, he developed an approach to phonology called 'prosodic phonology', which enables phonological features to be shared over successive phonemes rather than each phoneme having its own unique features (O’Donnell 2012, p. 6).

Nowadays, the SFL approach is used world-wide, especially in language education, and for a number of purposes like discourse analysis. It has continued to be closely associated with sociology even when a good number of linguistic theories deal with language in the form of mental practice. The Halliday's tradition, as an illustration, is more interested in the manner by which language is utilised in social settings so as to attain a specific target (O'Donnell, 2012 , p. 2). SFL, with regards to data, does not tackle the manner of language representation or process in the human brain, but would rather try to see discourses produced in the form of written or oral language and what is contained in the tests that are produced. Because of the concern of SFL with the use of language, great importance is placed on the function of language, such as what language is used for, rather than what language structure is all about and the manner by which it is composed (Matthiessen \& Halliday, 1997).

\section{SFL Compared to other Linguistic Traditions}

SFL has its distinctive respects in comparison with the other linguistic systems. For example, the systemic functional linguistics featured by Michael Halliday and the transformational 
generative linguistics represented by Noam Chomsky have been deemed as two of the most influential and pivotal traditions in the linguistic academic fields. However, both systems are distinct in many respects, but virtually make the same impacts. Yet there are a number of differences between these two linguistics systems. For instance, the systemic functional grammar (often SFG) studies the language through meaning (i.e. its function), while transformational generative grammar (often TGG) is a fully influential and developed version of linguistics through form. As an illustration, Halliday believed that linguistics should describe actual sentences with many functions and without a deep structure. In addition, he was concerned with the function of the sentence, or in other words, the writer's purpose in writing the sentence (Matthiessen \& Halliday 1997). Conversely, Chomsky maintained that linguistics should go beyond merely describing syntactic structures, and its purpose is to elucidate why language is structured in the way that it is. To summarize, Chomsky characterized form independently of function and meaning, while Halliday had good reasons to believe that function and meaning can help shape form (Bavali \& Sadighi 2008).

The second comparison is between Halliday's functional tradition and Bloomfield's structural tradition. The structural theory was featured by Leonard Bloomfield, who developed the structural linguistics in the United States during the 1930s and 1940s. However, Halliday insisted that the central concern of linguistics should be the study of the language through meaning, which was different from the dominant Bloomfield approach in American linguistics (Matthiessen \& Halliday 1997). Bloomfield rejected the possibility that linguistics analyzes meaning. He was fully convinced of the need for linguists to study oral language in lieu of studying written documents. The documents, for example, do not fully represent a spoken language due to the fact that language undergoes changes over time and what something means today might have meant a different thing altogether in the past (Hall \& Koerner, 1987).

\section{The Key Elements of SFL}

In SFL, a text is analyzed in four ways. They are as follows: Context, Semantics, Lexico-grammar, and Phonology (see figure 1). To begin with the context, context is classified as one of the central concerns, because it is integral to the overall process of making meaning. In fact, when language occurs in a context, it will relate to or is linked to a number of contexts (see figure 2) (Matthiessen \& Halliday 1997). They are:

\section{1- The Context of Culture [genres].}

2- The Context of Situation [the technical term for this is Register].

Halliday models the context of situation, where the aspects of the context relate intimately to the language used to create text, in terms of three important strands (Matthiessen \& Halliday, 1997) (see figure 3): They are:

A- Field: gives us an indication of the topic or what is being talked about. 
B- Tenor: gives us an indication of who is/are involved in the communication and the relationships between them.

C- Mode: gives us an indication of what part the language is playing in the interaction and what form it takes (written or spoken).

These three Register variables are used to explain people's intuitive understanding that individuals use different resources, different kinds and different parts from the system of language (Matthiessen \& Halliday 1997).

Inside the language itself, the SFL describes a model with three levels as a tristratal model of language (see figure 4). They are as follows:

1- Discourse-Semantics has three metafunctions. They are: Interpersonal metafunctions, Ideational metafunctions, and Textual metafunctions. (See figure 5).

2- Lexico-grammar includes both grammar and vocabulary in one stratum and represents the view of language in both lexis and grammar.

3- Phonology, orthography (or graphology) which refers to the sound system, the writing system, and the wording system (Eggins 2004, p.19).

Data from (figure 6) shows that SFL describes distinctive (sub)systems at both the level of lexico-grammar and the level of discourse semantics, which shapes the contextual variables in order to make the generalized meanings or metafunctions. Hence, the SFL model proposes that human language has evolved to make three generalized kinds of meanings; they are: Experiential meanings (clause as representation), Interpersonal meanings (clause as exchange), and Textual meanings (clause as message) (Eggins 2004, p.58-59).

1- The Experiential meanings are with the way reality is represented and the grammatical resources for construing our experience of the world around us, as to what is going on, who is involved in the going-on, and when, where, and how the goings-on are going on. One of its chief grammatical systems is classified as Transitivity (Matthiessen \& Halliday 1997). Transitivity includes a number of aspects:

A- The processes [in the verbal group]

$B$ - The participants (human/non-human) who are participating in these processes [in the noun group].

$C$ - The circumstances in which the processes occur and the when, where, and how they take place [in the prepositional phrase and adverbial group]. For instance: [Circumstance] in the open glade [participant] the wild rabbits [Process] danced [circumstance] with their shadows (Matthiessen \& Halliday 1997).

2- The interpersonal meanings are concerned with the interaction between speaker(s) and addressee(s). It is used to establish the speaker's role in the speech situation and relationship with others. One of its main grammatical systems is Mood and Modality (Matthiessen \& Halliday 1997). For example: (see figure \&) 
3- The textual meanings are concerned with the creation of text and the way we organize our meanings into the text that makes sense. One of the main textual systems is Theme and Rheme (Matthiessen \& Halliday, 1997). For instance: [Rheme] the wild rabbits danced with their shadows and [Theme] in the open glade.

\section{SFL as an Applicable Tradition}

SFL can be characterized as an "applicable" linguistics theory, which means it is designed to have the potential to be applied to solve problems that arise in communities around the world (Matthiessen \& Halliday 1997). Halliday (2008, p.189) states that his aim is to make a coherent tradition of language which is 'applicable,' in the sense that it can be beneficial to large numbers of people who are somehow engaging with language in the course of their work. SFL is well-known for its application in different fields such as healthcare, computational linguistics, translation, multimodal studies, education, and scholars are always discovering new areas of application (Matthiessen 2010). Additionally, it is renowned especially for the work on genre, cohesion, discourse analysis, register, appraisal, and so on, which have been taken up by scholars working in the humanities and social sciences.

In the recent years, SFL has been useful and helpful in fields such as linguistics language education (Christie \& Martin 1997), child language development (painter 1999), media discourse (Iedema 2003), history (Iedema 2003), educational linguistics (Christie \& Martin 1997), critical discourse analysis (Bloor \& Bloor 2007), and administrative language (Iedema 2003). Furthermore, SFL has also been applied to interpret the grammar of other semiotic modes, such as art (Ballantyre 1996) and visuals (Kress \& Leeuwen 2001). Consequently, SFL tradition is considered as a sensational international one, since it can be seen by the number of publications and conferences in SFL around the world. Briefly, it is clear that SFL can be applicable in unlimited fields.

\section{Examples of the Value of Applying SFL}

SFL has been applied as a valuable tool for a number of fields such as language education (Schleppegrell \& Colombi 2002). As an example, Gray and his colleagues (1999) worked with a sizeable number of learners who experienced difficulty with reading. They implemented a number of steps to improve the students' reading skills in their schools. First, SFL is well-versed in the educational framework known as "High Order Book Orientation." Next was the development of the learners' knowledge by Gray and his team regarding how meanings can be constructed through the help of language choices in texts. Improvements in the learners' reading literacy in their schools were made due to the practical and theoretical features of this work (Rose, Gray, \& Cowey, 1999).

SFL has also been a useful tool for child language development (Painter 1999). According to Knowles and Malmkjær (1996), SFL wielded a great influence on the manner of studying the language form of literary texts for children. SFL can also be used in the development of 
children's procedure in in-depth literary texts reading. In Australia, for example, government schools in New South Wales and Queensland have integrated the bases of the SFL for the teaching of grammar in their English syllabi. Instructions on SFL used in classroom work with children's literature have been made part of these documents. Children, due to this, have succeeded in understanding functional grammar and utilising it in enhancing their knowledge of literary texts. In addition, enjoyment was derived by studying language in this manner while children succeeded in gaining access to SFL theory (Williams, 1998). Based on the perspective of reading pedagogy it is quite obvious that children's knowledge of functional grammar was linked to more control of the speech's orthographic conventions and higher fluency scores in reading, in contrast to their peers (Williams, 1998). In conclusion, it has become obvious that a vital role in teaching and learning language is played by SFL.

\section{Benefits Associated with Working with SFL}

SFL is concerned with attempting to comprehend the manner by which language is utilised for various reasons and in various scenarios, thereby serving as a communicative motivation in the learning of language. Through the orderly functional grammar, for example, the students develop the ability to utilise language in different scenarios. Furthermore, they succeed in understanding the mode and category differences existing between written and spoken English. In addition, by analysing text, functional grammar succeeds in offering a considerable number of learners " a method of observing the relation between meaning and form in the different alternatives available in the English language grammatical systems, and the methods used by schools in interpreting knowledge" (Schleppegrell, 2004, p. 1). Accordingly, they attain academic excellence in their school. Nonetheless, written language control has emerged to include metaphor in grammar as an important language development feature of the schooling years. In addition, a good number of studies have demonstrated how written language growing control is capable of improving and extending the meaning and learning capacity (Torr \& Simpson, 2003). Beikoff (1996) reiterated that the use of functional grammar in teaching early literacy has proven to be successful. Furthermore, he remarked that functional grammar is both a new form of jargon and an alternative method of understanding, as sentences are not broken into separate parts while linking words shaping a meaning. Research, stated Jing (2010), demonstrates that SFG is capable of helping learners master English grammar from a grammatical point of view, and on the basis of their previous knowledge of traditional grammar and its application to language tasks recognise meanings in several frameworks.

\section{Conclusion}

To sum up, SFL was developed by Michael Halliday during the 1960s in the UK and then in Australia. SFL is considered a chief force in world linguistics, although it has only a short history. SFL is also considered as an influential tradition to linguistic study because it reflects the trend in linguistics development. In addition, it provides an innovative value from 


\section{Macrothink}

Journal for the Study of English Linguistics

ISSN 2329-7034 2016, Vol. 4, No. 1

functionalism and a useful tool for those who wish to analyze texts. This paper has aimed to present an introduction to Halliday's Systemic Functional Linguistics in various respects. They are: the background of the SFL as a linguistic tradition, SFL compared with other linguistic theories, the main elements of the SFL, SFL as an applicable theory, examples of the value of applying SFL, and lastly, the associated benefits with working with SFL.

\section{References}

Ballantyre, A. (1996). The Language of Displayed Art: Michael O'Toole.

Bavali, M., \& Sadighi, F. (2008). Chomsky's Universal Grammar and Halliday's Systemic Functional Linguistics: An Appraisal and a Compromise. Journal of Pan-Pacific Association of Applied Linguistics, 12(1).

Beikoff, K. (1996). How functional grammar works. Daily Telegraph. Retrieved June 10, 2013 from http://minerva.ling.mq.edu.au/network/debates/DailyTelegraph.html

Bloor, T., \& Bloor, M. (2007). The functional analysis of English (2nd ed.). London: Edward Arnold.

Christie, F., \& Martin, J. (1997). Genre and institutions: social processes in the workplace and school. London \& New York: Continuum.

Eggins, S. (2004). An introduction to systemic functional linguistics (2nd ed.). London: bloomsbury Academic.

Rose, D. Gray, B, \& Cowey, W. (1998). Scaffolding Reading and Writing for Indigenous Children in School. Canberra: Department of Education, Science and Training: Indigenous Education Branch and the University of Canberra.

Hall, R., \& Koerner, E. (1987). Leonard Bloomfield, essays on his life and work (1st ed.). Amsterdam: J. Benjamins Pub. Co.

Halliday, M., \& Matthiessen, C. (2004). An introduction to functional grammar (2nd ed.). London: Arnold.

Halliday, M. (2008). Complementarities in language (1st ed.). Beijing Shi: Commercial Press.

Iedema, R. (2003). Discourses of post-bureaucratic organization (1st ed.). Amsterdam: John Benjamins Pub.

Jing, C. (2010). An Empirical Study of Applying Functional Grammar to College English Teaching. Foreign Languages in China, 7(3), 59-64.

Knowles, M., \& Malmkjær, K. (1996). Language and control in children's literature (1st ed.). London: Routledge.

Kress, G., \& Van Leeuwen, T. (2001). Reading images (2nd ed.). London: Routledge.

Martin, J., \& Rose, D. (2003). Working with discourse (1st ed.). London: Continuum. 


\section{Macrothink}

Matthiessen, C. (2010). Systemic functional linguistics developing. Annual Review of Functional Linguistics, 2, 8-63.

Matthiessen, C., \& Halliday, M. (1997). Systemic functional grammar (1st ed.).

O’Donnell, M. (2012). Introduction to Systemic Functional Linguistics for Discourse Analysis. Language, Function and Cognition, pp. 1-8.

Painter, C. (2000). Learning language and learning though language in early childhood. Continuum, London.

Schleppegrell, M. (2004). The language of schooling: A functional linguistics perspective. Erlbaum, Mahwah.

Schleppegrell, M., \& Colombi, C. (2002). Developing advanced literacy in first and second languages (1st ed.). Mahwah, N.J.: Lawrence Erlbaum Associates.

Schleppegrell, M. (2004). The language of schooling (1st ed.). Mahwah, N.J.: Lawrence Erlbaum.

Torr, J. Simpson, A. (2003). The emergence of grammatical metaphor: literacy-oriented expressions in the everyday speech of young children. Macquarie University Research Online. Amsterdam, The Netherlands: John Benjamins.

Williams, G. (1998). 13 Children Becoming Readers: Reading and Literacy. Understanding Children's Literature: Key Essays from the International Companion Encyclopedia of Children's Literature, p. 151.

\section{Appendixes}

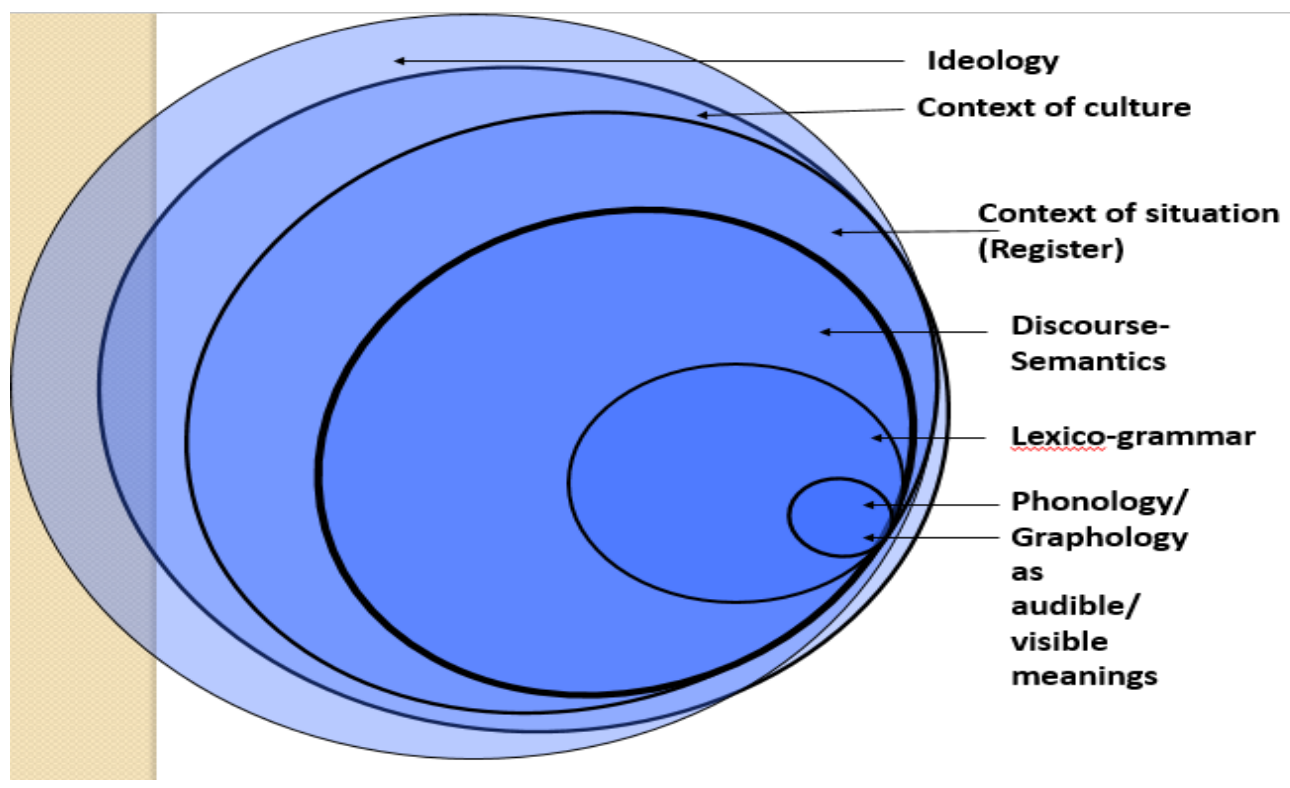

Figure 1. The Different Levels of the SFL

Source: John, 2014. Meaning as choice Course, LING 5004. The University of Adelaide [Image]. 


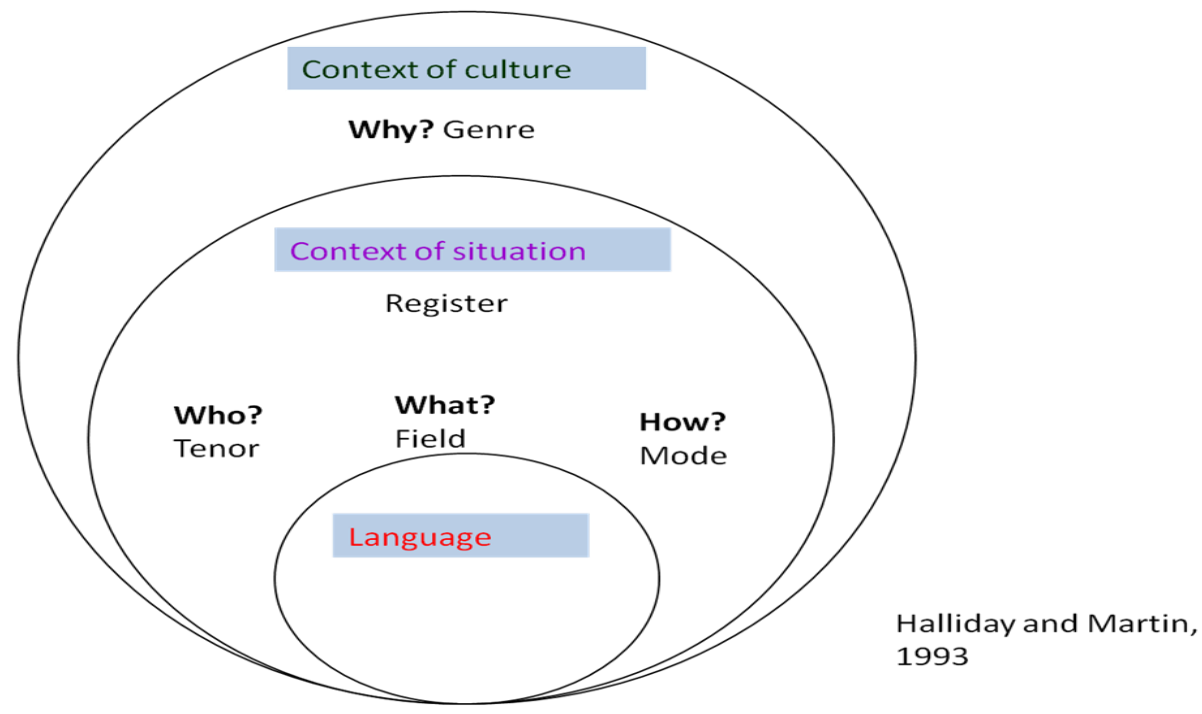

Figure 2. The Functional Model of Language

Source: Unknown, 2010. The Functional Model of Language. [Image] Available at: <http://whatslanguagedoinghere.files.wordpress.com/2013/03/functional-model.png> [Accessed 23 May. 2014].

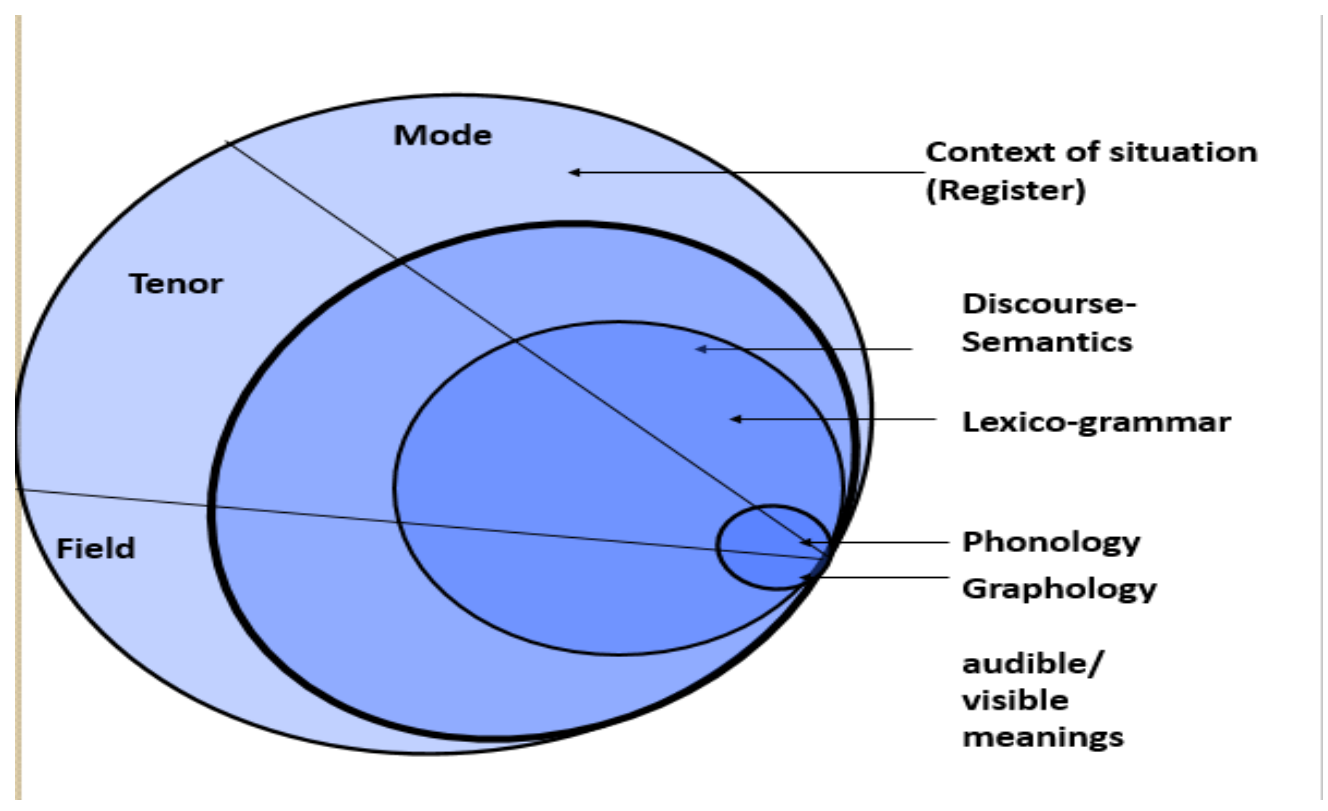

Figure 3. The Levels of the Context of Situation

Source: John, 2014. Meaning as choice Course, LING 5004. The University of Adelaide [Image]. 


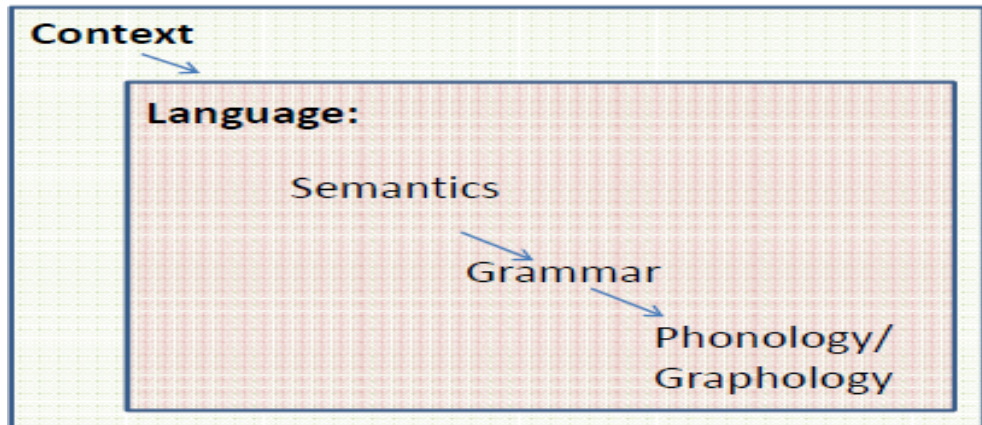

meanings

wordings

Soundings/

Spellings

Figure 4. Systemic Model of Language Strata

Source: O'Donnell, M., 2010. Language, Function, Cognition: Part 2: Systemic Functional Linguistics. Systemic Model of Language Strata. [Image] Available at: <http://web.uam.es/departamentos/filoyletras/filoinglesa/Courses/LFC-SFL/LFC-SFL-2010.pdf> [Accessed 23 May. 2014].

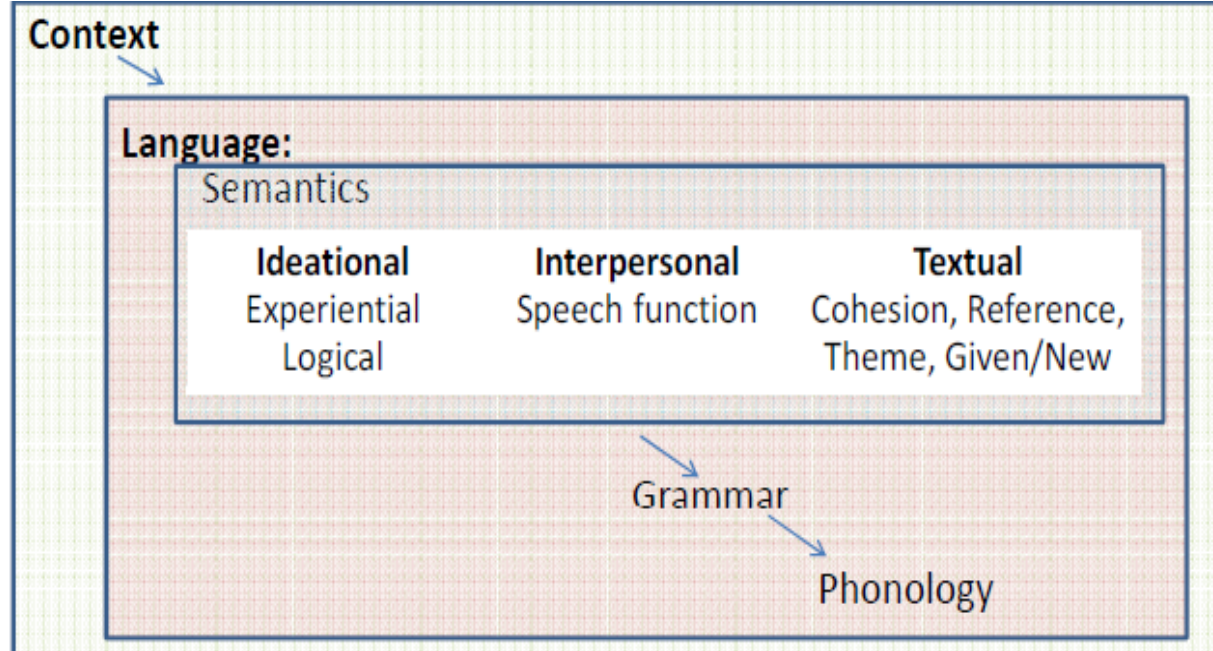

Figure 5. The Levels of Discourse-Semantics

Source: Halliday and Hasan (1989) Language, Context, and Text: Aspects of language in a social-semiotic perspective. Oxford, OUP. 


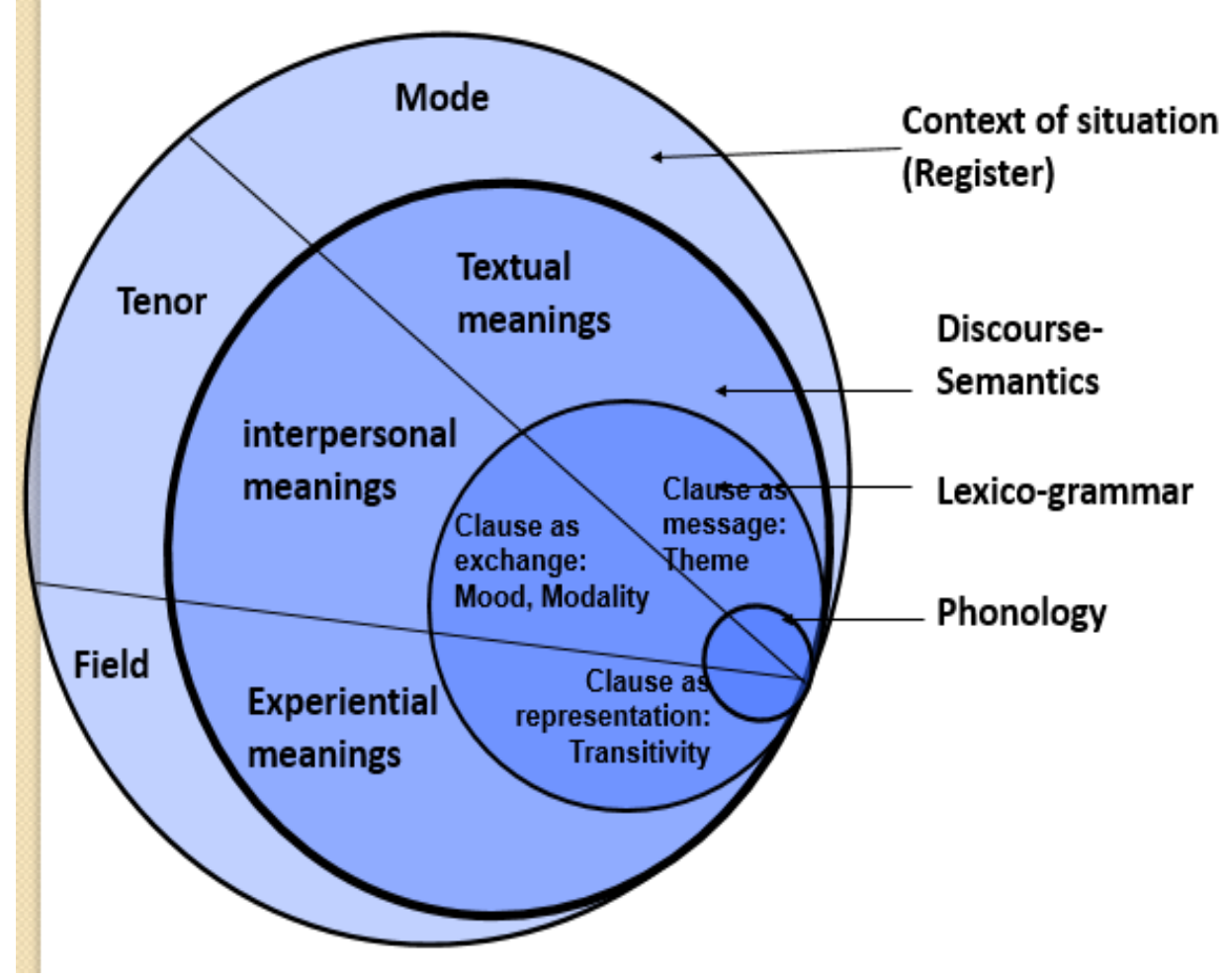

Figure 6. The (Sub)systems of Context of Situation, Discourse Semantics, and Lexico-grammar

Source: John, 2014. Meaning as choice Course, LING 5004. The University of Adelaide [Image].

\begin{tabular}{|l|l|l|l|l|}
\hline Sister Susie & 's & sewing & shirts & for soldiers \\
\hline Subject & Finite & Predicator & Complement & Adjunct \\
\hline Mood & Residue & \\
\hline
\end{tabular}

Figure 7. Mood Structure.

Source: Halliday, M. and Matthiessen, C., 2004. An introduction to functional grammar. 2nd ed. London: Arnold. P.121.

\section{Copyright Disclaimer}

Copyright for this article is retained by the author(s), with first publication rights granted to the journal.

This is an open-access article distributed under the terms and conditions of the Creative Commons Attribution license (http://creativecommons.org/licenses/by/3.0/). 